\title{
Aggregation of Argulus coregoni (Crustacea: Branchiura) on rainbow trout (Oncorhynchus mykiss): a consequence of host susceptibility or exposure?
}

\author{
M. BANDILLA ${ }^{1 *}$, T. HAKALAHTI ${ }^{1}$, P. J. HUDSON ${ }^{2}$ and E. T. VALTONEN ${ }^{1}$ \\ ${ }^{1}$ Department of Biological and Environmental Science, P.O. Box 35 (ya), FIN-40014, University of Fyväskylä, Finland \\ ${ }^{2}$ Department of Biology, Pennsylvania State University, University Park, PA 16902, USA
}

(Received 5 May 2004; revised 15 Fune and 22 Fuly 2004; accepted 22 Fuly 2004)

\section{S U M M A R Y}

By sampling individual rainbow trout, Oncorhynchus mykiss, at a fish farm we showed that Argulus coregoni were aggregated within their host population. The relative significance of susceptibility and exposure generating the observed pattern was tested using experimental infections. We examined, whether rainbow trout developed protective resistance mechanisms against the louse following a challenge infection and if there was variation between individual trout in their susceptibility to A. coregoni metanauplii. Fish were exposed to $20 \mathrm{~A}$. coregoni for 5, 25, 50, 85 or $120 \mathrm{~min}$ and the numbers attaching recorded. Three weeks later, developing argulids were removed and the experiment repeated with a standardized exposure of 20 metanauplii. Prior exposure of fish with A. coregoni did not reduce the total infection intensity compared to naïve fish, but fish gained infection more rapidly. We suggest that there is no protective acquired resistance of pre-exposed rainbow trout to subsequent Argulus exposure. The possibility that an immunosuppressive mechanism by argulids was acting enabling the higher attachment rate could be refuted since control individuals, not previously exposed to lice, gained the infection at a similar rate as the fish challenged twice. Our results do not indicate clear differences in susceptibility among individual fish but the transmission of metanauplii on fish seemed to be opportunistic and non-selective. Our results support the view that variation in exposure time, rather than differences in susceptibility of individual hosts, might be the key factor in generating the aggregated distribution of Argulus on their hosts.

Key words: Argulus coregoni, ectoparasite, aggregation, resistance, susceptibility, challenge infection.

\section{INTRODUCTION}

In general, ectoparasitic species exhibit an aggregated distribution on their hosts with a small proportion of the host population infested by the majority of the parasite population (reviewed by Shaw \& Dobson, 1995). This aggregated pattern can be generated through a number of mechanisms, although most can be classified as either a consequence of variability in exposure to infection, possibly associated with the spatio-temporal variation in infective stages, and/or heterogeneity between hosts in their susceptibility to infection (Anderson, Whitfield \& Dobson, 1978; Poulin \& Fitzgerald, $1989 a, b$; Grenfell et al. 1995; Shaw \& Dobson, 1995 ; Zelmer \& Arai, 1998; Wilson et al. 2002). Few studies have been able to show that either one or other of these mechanisms are dominant although there is increasing evidence from studies of fish parasites that variations in host exposure are the dominant cause (e.g. Karvonen et al. 2004).

* Corresponding author: Department of Biological and Environmental Science, P.O. Box 35 (ya), FIN-40014, University of Jyväskylä, Finland. Tel: +358142604238 . Fax: +35814260 2321. E-mail: matband@bytl.jyu.fi
Susceptibility of fish to ectoparasites can be influenced by the resistance mechanisms of innate and acquired (adaptive) immunity (e.g. Woo, 1992; Jones, 2001). Innate resistance against ectoparasitic copepods has been demonstrated for different salmonid species (e.g. Johnson \& Albright, 1992) and may reflect a historic association between a host population and its parasite (Jones, 2001; Dalgaard, Nielsen \& Buchmann, 2003). However, the results of several experiments on acquired immunity of fish against ectoparasites are conflicting. Many studies found minor and ineffective antibody responses (Grayson et al. 1991; MacKinnon, 1993) or none at all (e.g. Thoney \& Burreson, 1988; Sakuma et al. 1999), but Woo \& Shariff (1990) identified an effective acquired immunity response against copepods after a challenge infection.

Epizootics of the ectoparasitic fish lice, Argulus spp., can form a very serious threat to fish populations (Cross \& Stott, 1974; Menezes et al. 1990; Northcott, Lyndon \& Campbell, 1997). More specifically, Argulus coregoni (Thorell) has emerged as a significant problem for a number of Finnish fish farms during recent years (Hakalahti \& Valtonen, 2003; Hakalahti, Pasternak \& Valtonen, 2004). After hatching from egg clutches that are laid at the bottom 
of a water body, A. coregoni metanauplii attach themselves to fish, pierce the body of their hosts with highly specialized and modified mouthparts and feed on the host's blood and mucus (Stammer, 1959; LaMarre \& Cochran, 1992). The general weakening of the fish host by blood sucking together with the injection of a toxic anti-coagulant (Bower-Shore, 1940), in combination with secondary bacterial and fungal infections can lead to death of the host (Lester \& Roubal, 1995). Moreover, argulids also serve as a mechanical vector for the SVCV virus that causes spring viraemia in carp (Pfeil-Putzien, 1977; Ahne, 1985).

The objectives of this study were to describe the distribution of $A$. coregoni within a fish population and identify the mechanisms that generate this distribution pattern. Our hypothesis was that argulids are aggregated on their hosts, and this was caused by variations in exposure to infection. Variations in exposure to infective stages of fish lice are expected to exist in nature, because $A$. coregoni egg clutches were shown to be located in an aggregated manner (Hakalahti et al. 2004). Spatial heterogeneity in the existence of infective stages coupled with seasonal dynamics in their emergence is likely to cause variations of exposure especially when we consider that the hosts of $A$. coregoni are highly mobile salmonids (Shimura, 1983; Hakalahti \& Valtonen, 2003). Hosts that happen to be near emergence sites of $A$. coregoni during the most intensive spring hatching period are likely to be under highest exposure pressure. Also fish shoaling behaviour was shown to cause variability in exposure to lice (Poulin \& Fitzgerald, 1989a). The present paper explores the relative significance of susceptibility and exposure in generating the observed aggregated pattern using experimental infections on rainbow trout (Oncorhynchus mykiss) of the same age with varying exposure time. We addressed two specific questions. (1) Do rainbow trout acquire protective resistance to $A$. coregoni? (2) Do trout vary in their susceptibility to $A$. coregoni?

\section{MATERIALS AND METHODS}

\section{Field sampling}

To determine the distribution of Argulus coregoni within a fish population, 15 randomly chosen fish were sampled at a commercial fish farm in Central Finland 5 times between the 14th May and 3rd June 2002. The population consisted of about 16000 rainbow trout (Oncorhynchus mykiss) of $2+$ of age (mean total length \pm s.E. $=40 \mathrm{~cm} \pm 0 \cdot 45$ ). Fish were caught with seine and dip nets, anaesthetized in a water container with MS-222 and fish skin, gills and mouth cavities were inspected for argulids. Detached and removed lice were counted and preserved $(70 \%$ alcohol) for later length measurements. Sampled fish were released back to the canal. Water temperature increased during the period of capture from $9 \cdot 4{ }^{\circ} \mathrm{C}$ on 14th May to $17 \cdot 9^{\circ} \mathrm{C}$ on 3 rd June, mean temperature being $13.6{ }^{\circ} \mathrm{C}$ (s.E. \pm 0.68 ). The length of $A$. coregoni was measured from the edge of the carapax to the end of abdominal lobes with an ocular micrometer in a dissecting microscope.

\section{Exposure experiments}

Rainbow trout (Oncorhynchus mykiss) with an average mass of $66 \mathrm{~g}$ (s.E. $\pm 3 \cdot 4)$, total length of $14 \mathrm{~cm}$ (s.E. $\pm 0 \cdot 65)$ were obtained from a commercial fish farm together with stones carrying the egg clutches of Argulus coregoni. Prior to the experiment, fish were checked for any attached argulids to make sure that they were naïve in respect to Argulus infection, acclimated for 3 weeks in a 4000 litre flow-through tank and fed ad libitum with a commercial fish feed (Biomar, Finland).

The experiments were performed in aerated 30 litre containers, with water temperature adjusted to $17^{\circ} \mathrm{C}$. Since $A$. coregoni possess well-developed eyes (Meyer-Rochow, Au \& Keskinen, 2001) and Mikheev, Valtonen \& Rintamäki-Kinnunen (1998) demonstrated that vision was important when A. foliaceus (L.) was host searching, we used grey coloured containers to reduce unnatural light reflection and a moderate background lighting pattern of 12 lx (s.E. $\pm 0 \cdot 38)$.

Individual, naïve rainbow trout were selected at random and exposed to $20 \mathrm{~A}$. coregoni for periods of $5,25,50,85$ or $120 \mathrm{~min}$. All argulids used in the experiment were under $2 \mathrm{~h}$ of age. Each treatment consisted of 30 different fish, but in the $50 \mathrm{~min}$ exposure experiments only 21 replicates were used due to an unforeseen fall in the supply of $A$. coregoni metanauplii. Each of the 5 exposure times had a control unit of a similar number of fish that were treated in the same manner as exposed fish except they were sham-infected, i.e. they were maintained similarly and transferred to exposure tanks but the water was Argulus-free.

Following exposure, the number of attached metanauplii on each fish was established by counting the number of unattached metanauplii in the water. Fish were grouped into separate 300 litre flow-through tanks according to exposure time and infection level. Tanks with infection level I represented fish infected with 0-3 metanauplii, infection level II corresponded to 4-7, infection level III to 8-11, infection level IV to $12-15$, and infection level $\mathrm{V}$ to $16-20$ metanauplii on each fish, respectively. One of our objectives was to examine whether a challenge infection by $A$. coregoni would induce defensive responses in O. mykiss when fish were exposed to a second infection. Previous work has shown that low temperatures slow antibody synthesis in fish (Woo, 1992) and antibody development peaked several days to weeks after contact with antigens (e.g. Aaltonen, 


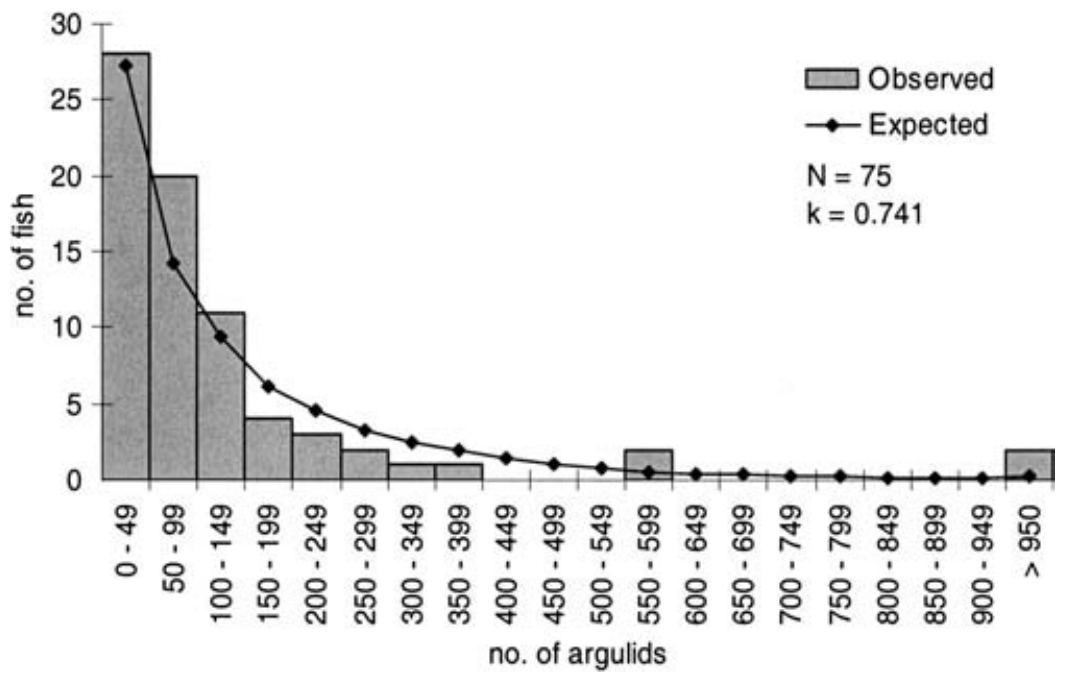

Fig. 1. Frequency distribution of Argulus coregoni on rainbow trout (Oncorhynchus mykiss) at a commercial fish farm. The line represents the fitted negative binomial distribution. Also indicated is the number of replicates and the estimate for $\mathrm{k}$ of the fitted negative binomial distribution.

Jokinen \& Valtonen, 1994). Therefore A. coregoni infected fish were kept in their tanks for 3 weeks after the first infection at a mean daily temperature of $17{ }^{\circ} \mathrm{C}( \pm 1 \cdot 0)$. Four fish died during the 3 week maintenance period.

After the maintenance period, each fish was caught with a dip net and anaesthetized with MS-222. $A$. coregoni that had developed were removed from the fish skin, counted and length recorded. After recovering from the narcotics $(24 \mathrm{~h})$, each fish was again exposed to 20 metanauplii using the same procedures and exposure periods that were used 3 weeks previously. During the second exposure, control fish (previously uninfected) were also treated with $A$. coregoni metanauplii. Five individual fish jumped out of their containers and were lost during re-exposure to metanauplii.

\section{Statistical analyses}

To compare the attachment success of Argulus coregoni on fish between the first, second and control exposure, the NLME package with gnls-function (R-System version 1.6.2) as explained by Pinheiro \& Douglas (2000) was used. A coregoni transmission in relation to time in the first, second and control exposures was fitted to a curve of the form:

$\mathrm{y}(\mathrm{x})=\Phi_{1}\left(1-\exp \left(-\exp \left(\Phi_{2}\right) \mathrm{x}\right)\right)$

where $\Phi_{1}=$ asymptote, $\Phi_{2}=2$ nd $\ln$ of the rate constant, $\mathrm{x}=$ time. The asymptote $\left(\Phi_{1}\right)$ is the saturation level of the curve at an indefinite time (x). The rate constant $\left(\Phi_{2}\right)$ expresses the half-life of the curve (the time at which infection intensity reached $50 \%$ of the maximum) in form of its 2nd natural logarithm.

A one-way ANOVA and a $t$-test were used to test for any significant trend of infected fish in the first exposure to show the same infection level again in the second exposure (SPSS version 10.0). Data were checked for normality and homogeneity of variance. Generalized linear models (glm) that included negative binomial error structure using SPlus were also used. In the glm-analysis we used the number of argulids attaching to fish in the second exposure as the dependent variable, the number attaching in the first exposure as the independent variable and time periods exposed and treatment (either control or re-exposed group) as factors.

The aggregation of juvenile argulids on fish was measured by using the variance:mean ratio index of dispersion $I_{D}=s^{2}(n-1) / x$, where $s^{2}=$ variance, $n=$ number of hosts sampled and $x=$ mean of attached argulids on fish (see Elliot, 1977). The $I_{D}$ was then compared to the Chi-square distribution with $n-1$ degrees of freedom. Statistical significance was accepted at $P<0 \cdot 05$. The fit of the negative binomial distribution to the parasite distribution in the fish sampled was estimated by equating the deviance to the residual degrees of freedom with a moment estimator in SPlus.

\section{RESULTS}

\section{Field sampling}

No differences were found in the mean numbers of Argulus coregoni on rainbow trout sampled 5 times between 14th May and 3rd June (Kruskal Wallis Test: $\chi^{2}=3 \cdot 562$; D.F. $\left.=4 ; P=0 \cdot 468\right)$. In all samples the infection prevalence of $A$. coregoni was $100 \%$ and in the pooled data the range of attached lice on fish was between 4 and 1390 individuals per fish (Fig. 1). $A$. coregoni were aggregated on the fish and were consistent with the fit of a negative binomial model with $k=0 \cdot 741$. Mean length of collected $A$. coregoni increased from $0.7 \mathrm{~mm}$ (s.E. \pm 0.007$)$ in the beginning of sampling on 14 th May to $2 \cdot 0 \mathrm{~mm}($ s.E. $\pm 0 \cdot 11)$ 
Table 1. Estimates of asymptote $\left(\Phi_{1}\right)$ values, half-lives $\left(\Phi_{2}\right)$ expressed in form of its 2nd natural logarithm and their $95 \%$ confidence intervals for comparing curves of the 1 st and 2 nd Argulus coregoni exposure and control and 2nd A. coregoni exposure

(In analysis A the 1st exposure was compared to the 2nd exposure and in analysis B the control exposure to the 2nd exposure, respectively.)

\begin{tabular}{llllll}
\hline \hline Analysis & Treatment & $\Phi_{1}$ & C.I. & $\Phi_{2}$ & C.I. \\
\hline A & 1st exposure & $17 \cdot 47$ & $(16 \cdot 23,18 \cdot 71)$ & $-3 \cdot 62$ & $(-3 \cdot 82,-3 \cdot 41)$ \\
A & 2nd exposure & $16 \cdot 52$ & $(13 \cdot 86,19 \cdot 20)$ & $-2 \cdot 72$ & $(-3 \cdot 19,-2 \cdot 23)$ \\
B & Control exposure & $16 \cdot 81$ & $(15 \cdot 12,18 \cdot 51)$ & $-2 \cdot 65$ & $(-3 \cdot 11,-2 \cdot 19)$ \\
B & 2nd exposure & $16 \cdot 53$ & $(15 \cdot 81,17 \cdot 25)$ & $-2 \cdot 71$ & $(-2 \cdot 91,-2 \cdot 52)$ \\
\hline \hline
\end{tabular}
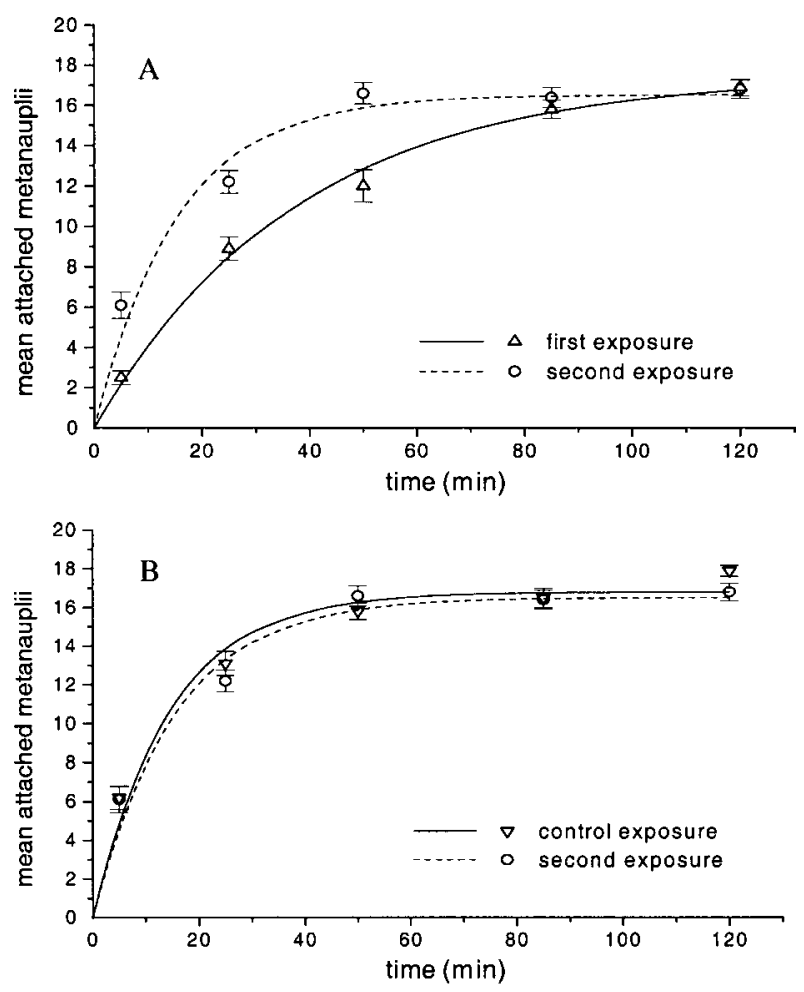

Fig. 2. Comparison of Argulus coregoni metanauplii infection success during (A) the first and second exposure of challenged fish (Oncorhynchus mykiss) and (B) control and challenged fish in the second exposure. Fish that were challenged with argulids in the first exposure carried the parasite burden for 3 weeks after which they were re-exposed to metanauplii. Control fish had no contact with $A$. coregoni during the first exposure (sham infection) but were exposed to metanauplii during the second exposure. Bars represent standard error of the means. See Table 1 for asymptote and rate constant values for fitted curves.

at the end of sampling on 3rd June (Mann-Whitney Test: $\mathrm{U}=0.000 ; P<0 \cdot 001)$.

\section{Transmission to naïve and re-exposed fish}

The number of Argulus coregoni metanauplii infecting fish in the second exposure was significantly higher than that recorded in the first exposure $(P<0 \cdot 001$, Fig. 2A). The half-life of the curve in the first exposure $(26 \mathrm{~min})$ was more than twice that of the second exposure $(10 \mathrm{~min})$. However, transmission curves of all treatments saturated at the same asymptote after $120 \mathrm{~min}$ of exposure (first vs second exposure: $P=0.193$; second $v$ s control exposure: $P=0.569$ ), when $80 \%$ of $A$. coregoni attached on the fish. No significant difference was seen when the second exposure was compared to the curve of the control fish $(P=0 \cdot 549$, Fig. 2B). Asymptote values and rate constants used for comparing different exposure times are shown in Table 1. Since there is an overall aggregated distribution of argulids on fish we undertook a generalized linear model with negative binomial errors. Only the period of infection was identified as a significant factor $\left(\mathrm{F}_{280,1}=136 \cdot 28\right.$, $P<0 \cdot 001)$ and neither previous infection level nor treatment or any two or three way interaction as significant showing that there was no evidence of the development of resistance to reinfection.

\section{Host susceptibility}

The comparison of fish belonging to different infection levels in exposure times of $5 \mathrm{~min}(P=0.283)$, $25 \mathrm{~min}(P=0 \cdot 230), 50 \mathrm{~min}(P=0 \cdot 518)$ and $120 \mathrm{~min}$ $(P=0 \cdot 980)$ did not show any significant association with similar levels of infection during the second exposure (Table 2). Only in the $85 \mathrm{~min}$ treatment was the susceptibility trend during the first exposure repeated in the second exposure $(P=0 \cdot 002)$.

The variance to mean ratios of attached argulids during different exposures are represented in Fig. 3. The index of dispersion $\left(I_{D}\right)$ showed that attached argulids were aggregated on fish in the 5 min treatments of the control exposure and the second exposure. This pattern changed from a random to a more even distribution with the variance falling to be less than the mean with increasing exposure time.

\section{Persistence on fish}

From all Argulus coregoni metanauplii that attached $(N=1574)$ during the first exposure, $38 \%$ were found on fish after 3 weeks maintenance at $17{ }^{\circ} \mathrm{C}$. The mean length of the lice had increased from $0.7 \mathrm{~mm}$ 
Table 2. Mean attached Argulus coregoni metanauplii on rainbow trout (Oncorhynchus mykiss) during the first and second exposure in different infection levels

(Statistical tests were performed separately within each exposure time. Also the number of fish in each infection level is represented $(n)$.)

\begin{tabular}{|c|c|c|c|c|}
\hline $\begin{array}{l}\text { Exposure time } \\
(\mathrm{min})\end{array}$ & Infection level & $\begin{array}{l}\text { Mean attachment } \\
\text { in } 1 \text { st exposure }\end{array}$ & $\begin{array}{l}\text { Mean attachment } \\
\text { in } 2 \text { nd exposure }\end{array}$ & Analysis \\
\hline 5 & $\begin{array}{l}\text { I }(n=21) \\
\text { II }(n=9)\end{array}$ & $\begin{array}{l}1 \cdot 5 \\
4 \cdot 0\end{array}$ & $\begin{array}{l}6 \cdot 7 \\
5 \cdot 0\end{array}$ & $\begin{array}{l}\text { Student's } t \text {-test: } \\
t_{27}=1 \cdot 096, P=0.283\end{array}$ \\
\hline 25 & $\begin{array}{l}\text { I }(n=1) \\
\text { II }(n=11) \\
\text { III }(n=11) \\
\text { IV }(n=7)\end{array}$ & $\begin{array}{r}3 \cdot 0 \\
6 \cdot 3 \\
9 \cdot 3 \\
13 \cdot 3\end{array}$ & $\begin{array}{r}6 \cdot 0 \\
12 \cdot 2 \\
12 \cdot 7 \\
12 \cdot 3\end{array}$ & $\begin{array}{l}\text { ANOVA: } \\
\mathrm{F}_{3,26}=1 \cdot 531, P=0 \cdot 230\end{array}$ \\
\hline 50 & $\begin{array}{l}\text { II }(n=4) \\
\text { III }(n=3) \\
\text { IV }(n=11) \\
\text { V }(n=3)\end{array}$ & $\begin{array}{r}6 \cdot 0 \\
9 \cdot 0 \\
13 \cdot 8 \\
16 \cdot 0\end{array}$ & $\begin{array}{l}16 \cdot 3 \\
17 \cdot 0 \\
16 \cdot 1 \\
18 \cdot 3\end{array}$ & $\begin{array}{l}\text { ANOVA: } \\
\mathrm{F}_{3,13}=0 \cdot 796, P=0.518\end{array}$ \\
\hline 85 & $\begin{array}{l}\text { III }(n=1) \\
\text { IV }(n=13) \\
\text { V }(n=16)\end{array}$ & $\begin{array}{l}10 \cdot 0 \\
13 \cdot 8 \\
17 \cdot 8\end{array}$ & $\begin{array}{l}10 \cdot 0 \\
15 \cdot 5 \\
17 \cdot 6\end{array}$ & $\begin{array}{l}\text { ANOVA: } \\
\mathrm{F}_{2,27}=7 \cdot 640, P=0 \cdot 002\end{array}$ \\
\hline 120 & $\begin{array}{l}\text { IV }(n=5) \\
\text { V }(n=24)\end{array}$ & $\begin{array}{l}14 \cdot 5 \\
17 \cdot 8\end{array}$ & $\begin{array}{l}16 \cdot 8 \\
16 \cdot 8\end{array}$ & $\begin{array}{l}\text { Student's } t \text {-test: } \\
t_{25}=-0 \cdot 250, P=0.980\end{array}$ \\
\hline
\end{tabular}

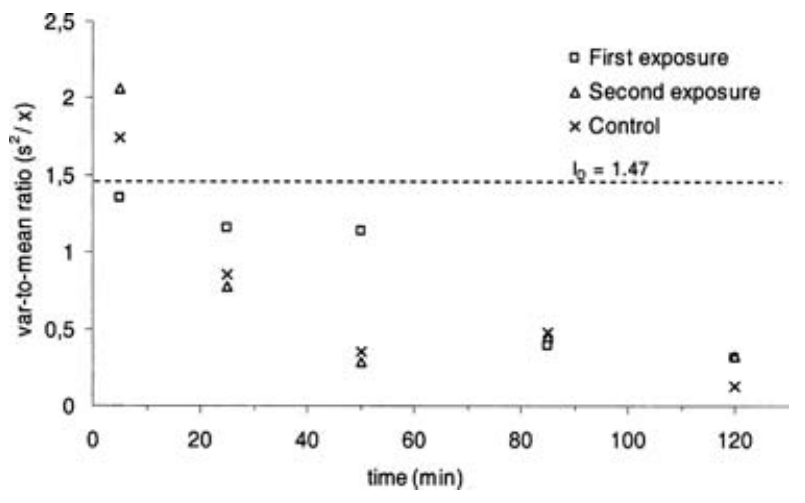

Fig. 3. The relationship between the variance to mean ratios of the number of attached Argulus coregoni metanauplii per host (Oncorhynchus mykiss) and duration of host exposure to infection. Also given is the variance : mean ratio index of dispersion, $I_{D}=s^{2}(n-1) / x$, above which the distribution is aggregated (see Elliot, 1977).

(S.E. $\pm 0 \cdot 004)$ just after hatching to $2.9 \mathrm{~mm}$ (S.E. \pm $0 \cdot 07)$ at removal from the fish body.

\section{DISCUSSION}

Sampling of fish from a commercial fish farm showed that Argulus coregoni is aggregated on their hosts. We explored the relative significance of duration of exposure and susceptibility of rainbow trout (Oncorhynchus mykiss) in generating the aggregation of lice on their host population by experimentally reexposing fish to $A$. coregoni metanauplii with varying exposure periods and following the pattern of reinfection. The infection rate of $A$. coregoni metanauplii during the second exposure was significantly higher than during the first exposure, but did not differ from the infection of control and previously uninfected fish, which were exposed to metanauplii after a 3 week argulid-free maintenance period. The half-lives of the curves in the second and in the control exposure were similar and both significantly shorter than during the first exposure, indicating that it was easier for the lice to attach in the second exposure. Hence, the challenge infection in the present study did not show the development of a protective acquired resistance in rainbow trout, against juvenile A. coregoni. This was confirmed by analysis using a generalized linear model.

The exposure methods, maintenance of fish and abiotic parameters such as temperature and lightintensity were kept standard in all experiments and the source of Argulus metanauplii was the same. However, one potentially confounding reason for the increased infection success in the exposed control and second exposure may be associated with the fact that the fish were older and had been in captivity for longer. Handling, tagging and confinement periods are known to stress fish (e.g. Salonius \& Iwama, 1993) and stressed fish are more susceptible to pathogenic infections (e.g. MacKinnon, 1998). Furthermore, Fry (1971) showed that the activity of fish is decreased by stress and variation in host behaviour can influence infection rates of crustacean ectoparasites (Poulin, Rau \& Curtis, 1991). This would suggest that reduced movement of fish during the second exposure, as a consequence of stress, may have made it easier for metanauplii to attach. This hypothesis is supported by Mikheev et al. (1998) and Mikheev et al. (2000) who emphasized the role of fish swimming activity in attachment success of argulids. Moreover, Poulin \& Fitzgerald (1989b) identified host behaviour as a possible factor that could lead to 
increased infection by Argulus. In nature, inactive fish may remain close to emergence sites of $A$. coregoni metanauplii at the bottom of a water body (see Mikheev et al. 2001; Hakalahti et al. 2004) and this would lead to increased exposure. Indeed, variation in fish behaviour seems to be the most likely mechanism that would generate the aggregation patterns in the A. coregoni-host relationship. As the attachment success of argulids in relation to time was similar on control fish during the second exposure and on the challenged fish, which were held in tanks infested by argulids over 3 weeks, any possible immunosuppressive effects invoked by the parasite that would lead to higher numbers attaching seem to be of little significance.

Woo \& Shariff (1990) proposed that acquired immunity can significantly reduce copepodid ectoparasite infection. However, the results from our work are in line with the majority of previous studies that have found no evidence of a protective specific immune response by fish against copepod lice (for a review see Tully \& Nolan, 2002). Fish hormones are detectable in the water when fish are stressed (Malyushina, Kasumyan \& Marusov, 1991) and while adult argulids can respond to host chemical cues (Herter, 1927; Galarowicz \& Cochran, 1991; Mikheev et al. 2000) some recent studies have shown that olfactory stimulation did not play a role in the behaviour of juvenile $A$. coregoni (Mikheev, Pasternak \& Valtonen, 2004). Therefore we postulate that reduced movement of fish is probably the main factor that may have increased attachment success of $A$. coregoni during the second exposure.

By placing fish into groups according to infection levels, after the first exposure, we were able to examine if there was a tendency for infested fish to show the same relative infection level on re-exposure. Note that we did not tag individual fish in an attempt to reduce stress. A repeated susceptibility pattern was seen only in the $85 \mathrm{~min}$ exposure but no trend was detectable during all other exposure times suggesting the attachment behaviour of $A$. coregoni was opportunistic and not selective. This result is also supported by examination of the variance-tomean relationship $\left(s^{2} / x\right)$ during the exposures and by the generalized linear model that showed the level of infection was simply a consequence of the period exposed to infective stages. Interestingly, in the field studies argulids were aggregated on their hosts but $\mathrm{k}$ of the fitted negative binomial distribution was $\sim 0 \cdot 7$, not a high degree of aggregation compared with other parasites (e.g. Anderson \& May, 1991).

An aggregated distribution of argulids among fish would be expected if there were individual variations in susceptibility of fish. This variation in susceptibility could develop through acquired immunity in which case the aggregation should increase with the total number and the period of exposure to parasites. Unlike many other host-parasite systems (e.g.
Anderson et al. 1978), we observed a decrease in the degree of aggregation of Argulus with time, under laboratory conditions. Only during short exposure periods were the argulids aggregated. This is counter to what would be expected from the hypothesis that acquired immunity would generate aggregation. Indeed, this may be a consequence of the unique relationship between the 'predatory' behaviour of Argulus species and their hosts (Poulin \& FitzGerald, 1989 a; Mikheev et al. 2000). Compared to the adult stages, the metanauplii carry a relatively low energy store and have poorly developed swimming legs (Stammer, 1959) and since energy expenditure for locating hosts is high (Mikheev et al. 2000) they must attach to hosts rapidly. In contrast, the adult argulids have a good sensory ability, improved swimming capability and a higher energy store and are able to switch to a preferred host, thereby increasing their level of fitness. Pasternak, Mikheev \& Valtonen (2000) showed that $A$. foliaceus indeed detached and attached repeatedly during their ontogeny. However, the ability to switch and select a host develops slowly in A. coregoni (see Mikheev et al. 2004) and so we propose that host switching and selection was probably unlikely during the relatively short period of our experiments but could be expected over a longer time period. Similar results were noted in a study by Bower-Shore (1940); sticklebacks in both good condition and others in an advanced state of disease had all been infected by $A$. foliaceus indiscriminately.

In our field studies we recorded an aggregated distribution of $A$. coregoni on their hosts, although lice were at juvenile stage (about $2 \mathrm{~mm}$ in length). This observation coupled with the findings from our experimental infection studies lead us to suppose that, in this system, variation in exposure to infective stages rather than differences in susceptibility between the fish, generated through acquired immunity, was the factor generating aggregation. While this will be influenced by the aggregated availability of argulids in the fish ponds (Hakalahti et al. 2004), we emphasize the role that a combination of ecological and the host-parasite behavioural changes can play in generating the observed distribution pattern. For the future, we therefore need experiments to investigate if the distribution of $A$. coregoni juvenile stages on fish remains or could change in different stages during the ontogeny and if fish can use behavioural defence mechanisms to avoid infection. As the argulids mature we would expect them to develop host-switching behaviours, in an attempt to reduce intra-specific competition on the host and this would lead to a more regular distribution of argulids among fish. In short, we propose that argulids may exhibit an ideal free distribution whereby they distribute themselves evenly through even aged fish. At the same time this distribution may be influenced by the host density, relative quality of the host habitat 
and the availability of potential mating partners of argulids.

In conclusion, the results from this study suggest that there is no protective acquired resistance of pre-exposed fish to subsequent Argulus infection, but stress levels probably increase attachment success. As no groups of fish were specifically preferred nor avoided by Argulus metanauplii the infection strategy during early life stages seems to be opportunistic and non-selective. Differences in encounter rates (Fryer, 1965; Boxshall, 1974), duration of exposure to parasite infective stages and host behaviour, especially the ability of the host to escape and avoid subsequent movement of argulids appear important in generating the aggregated distribution of argulids observed on fish.

The authors gratefully thank H. Häkkinen and the staff of Konnevesi Research Station for help during the experiments. The manuscript benefited from discussions with Andy Dobson. Special thanks to P. J. Aphalo for advice concerning the statistical analyses. T.H. was financially supported by the Foundation for Research of Natural resources in Finland. Savon Taimen Oy kindly provided the needed fish specimens. This work was part of the SUNARE project (Research Program for Sustainable Use of Natural Resources) financed by the Academy of Finland.

\section{REFERENCES}

Aaltonen, T. M., JOKinen, E. I. \& VALtonen, E. T. (1994).

Antibody synthesis in roach (Rutilus rutilus); analysis of antibody secreting cells in lymphoid organs with ELISPOT-assay. Fish and Shellfish Immunology $\mathbf{4}$, 129-140.

AHNE, w. (1985). Argulus foliaceus L. and Piscicola geometra $\mathrm{L}$. as mechanical vectors of spring viraemia of carp virus (SVCV). Fournal of Fish Diseases 8, 241-242.

ANDERSON, R. M., WHITFIELD, P. J. \& DOBSON, A. P. (1978).

Experimental studies of infection dynamics: infection of the definitive host by the cercariae of Transversotrema patialense. Parasitology 77, 189-200.

ANDERSon, R. M. \& MAY, R. M. (1991). Infectious Disease of Humans : Dynamics and Control. Oxford University Press, Oxford.

BOWER-SHORE, C. (1940). An investigation of the common fish louse, Argulus foliaceus (Linn.). Parasitology 32, 361-371.

BOXshall, G. A. (1974). The population dynamics of Lepeoptheirus pectoralis (Müller): dispersion pattern. Parasitology 69, 373-390.

Cross, D. G. \& STOTT, B. (1974). The effect of Argulus foliaceus L. on the growth and mortality of a grass carp population. Fournal of Institutional Fisheries Management 5, 39-42.

DALGAARD, M. B., NIELSEN, C. V. \& BUChMANN, K. (2003). Comparative susceptibility of two races of Salmo salar (Baltic Lule river and Atlantic Conon river strains) to infection with Gyrodactylus salaris. Diseases of Aquatic Organisms 53, 173-176.

Elliot, J. M. (1977). Statistical Analysis of Samples of Benthic Invertebrates. Freshwater Biological Association, Ambleside.
FRY, F. E. J. (1971). The effect of environmental factors on the physiology of fish. In Fish Physiology, 6 (ed. Hoar, W. S. \& Randall, D. J.), pp. 1-98. Academic Press, London, New York.

FRYER, G. (1965). Habitat selection and gregarious behaviour in parasitic crustaceans. Crustaceana $\mathbf{1 0}$, 199-209.

Galarowicz, T. \& Cochran, P. A. (1991). Responses by the parasitic Crustacean Argulus japonicus to host chemical cues. Fournal of Freshwater Ecology 6, 455-456.

GRAYSON, T. H., JENKINS, P. G., WRATHMELL, A. B. \& HARRIS, J.E. (1991). Serum responses to the salmon louse Lepeoptheirus salmonis (Krøyer, 1838), in naturally infected salmonids and immunised rainbow trout, Oncorhynchus mykiss (Walbaum), and rabbits. Fish and Shellfish Immunology 1, 141-155.

GRENFELL, B. T., WILSON, K., ISHAM, V. S., BOYD, H. E. G. \& DIETZ, K. (1995). Modelling patterns of parasite aggregation in natural populations: trichostrongylid nematode-ruminant interactions as a case study. Parasitology 111 (Suppl.), S135-S151.

hakalahti, T. \& Valtonen, E. T. (2003). Population structure and recruitment of the ectoparasite Argulus coregoni Thorell (Crustacea: Branchiura) on a fish farm. Parasitology 127, 79-85.

hakalahti, T., Pasternak, A. F. \& VAltonen, E. T. (2004). Seasonal dynamics of egg laying and egg-laying strategy of the ectoparasite Argulus coregoni (Crustacea: Branchiura). Parasitology 128, 655-660.

HERTER, K. (1927). Reizphysiologische Untersuchungen an der Karpfenlaus (Argulus foliaceus L.). Zeitschrift für vergleichende Physiologie 5, 283-370.

JOHNSON, S. C. \& ALBRIGHT, L. J. (1992). Comparative susceptibility and histopathology of the response of naïve Atlantic, chinook and coho salmon to experimental infection with Lepeoptheirus salmonis (Copepoda: Caligidae). Diseases of Aquatic Organisms 14, 179-193.

JONES, S. R. M. (2001). The occurrence and mechanisms of innate immunity against parasites in fish. Developmental and Comparative Immunology 25, 841-852.

KARVONEN, A., HUDSON, P. J., SEPPÄLÄ, O. \& VALTONEN, E. T. (2004). Transmission dynamics of a trematode parasite: exposure, acquired resistance and parasite aggregation. Parasitology Research 92, 183-188.

LAMARRE, E. \& COChran, P. A. (1992). Lack of host species selection by the exotic parasitic crustacean, Argulus japonicus. Fournal of Freshwater Ecology 7, 77-80.

LESTER, R. J. G. \& Roubal, F. R. (1995). Phylum Arthropoda. In Fish Diseases and Disorders (ed. Woo, P. T. K.), pp. 475-599. Cab International, Wallingford, UK.

Mackinnon, B. M. (1993). Host response of Atlantic salmon (Salmo salar) to infection by sea lice (Caligus elongatus). Canadian Fournal of Fisheries and Aquatic Sciences 50, 789-792.

Mackinnon, B. M. (1998). Host factors important in sea lice infestations. Fournal of Marine Science 55, 188-192.

MALYUSHINA, G. A., KaSUMYan, A. O. \& MARUSOV, E. A. (1991). Ecological aspects of chemical signals in fish. Fournal of Ichthyology 31, 1-7.

MENEZES, J., RAMOS, M. A., PEREIRA, T. G. \& DA SILVA, A. M. (1990). Rainbow trout culture failure in a small lake as a result of massive parasitosis related to careless fish introductions. Aquaculture 89, 123-126. 
MEYER-ROCHOW, V. B., AU, D. \& KESKINEN, E. (2001). Photoreception in fish lice (Branchiura): the eyes of Argulus foliaceus Linné, 1758 and A. coregoni Thorell, 1865. Acta Parasitologica 46, 321-331.

MiKHEEV, V. N., VALTONEN, E. T. \& RINTAMÄKI-KINNUNEN, P. (1998). Host searching in Argulus foliaceus L.

(Crustacea: Branchiura): the role of vision and selectivity. Parasitology 116, 425-430.

MIKHEEV, V. N., MIKHEEV, A. V., PASTERNAK, A. F. \& VALTONEN, E. T. (2000). Light-mediated host searching strategies in a fish ectoparasite, Argulus foliaceus L. (Crustacea: Branchiura). Parasitology 120, 409-416.

MikHEev, V. N., PASTERNAK, A. F., VAltonen, E. T. \& LANKINEN, Y. (2001). Spatial distribution and hatching of overwintered eggs of a fish ectoparasite, Argulus coregoni (Crustacea: Branchiura). Diseases of Aquatic Organisms 46, 123-128.

MikHEev, V. N., PASTERnAK, A. F. \& VALTONEN, E. T. (2004).

Tuning host specificity during the ontogeny of a fish ectoparasite: behavioural responses to host-induced cues. Parasitology Research 92, 220-224.

NORTHCOTT, S. J., LYNDON, A. R. \& CAMPBELL, A. D. (1997). An outbreak of freshwater fish lice, Argulus foliaceus L., seriously affecting Scottish stillwater fishery. Fisheries Management and Ecology 4, 73-75.

PASTERnak, A. F., MikHEev, V. N. \& VALtonen, E. T. (2000). Life history characteristics of Argulus foliaceus L. (Crustacea: Branchiura) populations in Central Finland. Annales Zoologici Fennici 37, 25-35.

PFEIL-PUTZIEN, C. (1977). Experimentelle Übertragung der Frühjahrsvirämie (spring viraemia) der Karpfen durch Karpfenläuse (Argulus foliaceus). Zentralblatt für Veterinärmedizin, Reihe B 25, 319-323.

PInHeiro, J. C. \& Douglas, M. B. (2000). Statistics and Computing: Mixed-effects Models in S and S-Plus. Springer, New York.

POULIN, R. \& FITZGERALD, G. J. (1989a). Shoaling as an anti-ectoparasite mechanism in juvenile sticklebacks (Gasterosteus spp.). Behavioural Ecology and Sociobiology 24, 251-255.

POUlin, R. \& FITZGERALD, G. J. (1989b). A possible explanation for the aggregated distribution of Argulus canadensis Wilson, 1916 (Crustacea: Branchiura) on juvenile sticklebacks (Gasterosteidae). Fournal of Parasitology 75, 58-60.

POULIN, R., RAU, M. E. \& CURTIS, M. A. (1991). Infection of brook trout fry, Salvelinus fontinalis, by ectoparasitic copepods: the role of host behaviour and initial parasite load. Animal Behaviour 41, 467-476.

SAKUMA, K. M., RALSTON, S., LANARZ, W. H. \& EMBURY, M. (1999). Effects of the parasitic copepod Cardiodectes medusaeus on the lanternfishes Diaphus theta and Tarletonbeania crenularis off central California. Environmental Biology of Fishes 55, 423-430.

SALONIUS, K. \& IWAMA, G. K. (1993). Effects of early rearing environment on stress response, immune function, and disease resistance in juvenile coho (Oncorhynchus kisutsch) and chinook salmon (O. tshawytscha). Canadian Fournal of Fisheries and Aquatic Sciences 50, 759-766.

SHAW, D. J. \& DOBSON, A. P. (1995). Patterns of macroparasite abundance and aggregation in wildlife populations: a quantitative review. Parasitology 111 (Suppl.), S111-S133.

SHIMURA, s. (1983). Seasonal occurrence, sex ratio and site preference of Argulus coregoni Thorell (Crustacea: Branchiura) parasitic on cultured freshwater salmonids in Japan. Parasitology 86, 537-552.

Stammer, H. J. (1959). Beiträge zur Morphologie, Biologie und Bekämpfung der Karpfenläuse. Zeitschrift für Parasitenkunde 19, 135-208.

THONEY, D. A. \& BURRESON, E. M. (1988). Lack of a specific humoral response in Leiostomus xanthurus (Pisces: Scianidae) to parasitic copepods and monogeneans. Fournal of Parasitology 74, 191-194.

TULLY, O. \& NOLAN, D. T. (2002). A review of the population biology and host-parasite interactions of the sea louse Lepeoptheirus salmonis (Copepoda: Caligidae). Parasitology 124 (Suppl.), S165-S182.

WILSON, K., BJØRNSTAD, O. N., DOBSON, A. P., MERLER, S., POGLAYEN, G., RANDOLPH, S. E., READ, A. F. \& SKORPING, A. (2002). Heterogeneities in macroparasite infections: patterns and processes. In The Ecology of Wildlife Diseases (ed. Hudson, P. J., Rizzoli, A., Grenfell, B. T., Heesterbeek, H. \& Dobson, A. P.), pp. 6-44. Oxford University Press, Oxford.

woO, P. T. K. (1992). Immunological responses of fish to parasitic organisms. Annual Review of Fish Diseases, pp. 339-366.

WOO, P. T. K. \& SHARIFF, M. (1990). Lernaea cyprinacea L. (Copepoda: Caligidae) in Helostoma temminicki Cuvier \& Valenciennes: the dynamics of resistance in recovered and naïve fish. Fournal of Fish Diseases 13, 485-493.

ZELMER, D. A. \& ARAI, H. P. (1998). The contributions of host age and size to the aggregated distribution of parasites in yellow perch, Perca flavescens, from Garner Lake, Alberta, Canada. Fournal of Parasitology 84, 24-28. 